\title{
PERILAKU PEGAWAI DAN DAMPAKNYA PADA EFEKTIVITAS TENAGA KEPENDIDIKAN
}

\author{
Mohammad Zainul \\ Program Pasca Sarjana Magister Manajemen Universitas Islam Kalimantan \\ Jl. Adhyaksa No. 2 Kayutangi, Banjarmasin \\ e-mail: zainul38@yahoo.co.id
}

\begin{abstract}
The public spotlight on performance is getting bigger, especially regarding the sub-optimal and the minimum standard of apparatus performance. Therefore attention to the performance and effectiveness of the organization's work is a central topic to be a busy topic of discussion. This study examines the extent of the influence of employee performance on the organizational effectiveness of the District Education Office of Tanah Bumbu. To administer this condition, the apparatus's behavioral dimensions include abilities, skills, knowledge, attitudes, and motivations while the dimensions of organizational effectiveness on work productivity, efficiency, and job satisfaction. Skills, knowledge, attitudes, and motivation as an organizational asset, so that the quality of the human resources of the organization concerned can be relied upon in carrying out work and readiness to face changes and challenges in the future.
\end{abstract}

Keywords: Employee behavior, work effictiveness, performance, performance appraisal, HR quality

\begin{abstract}
Abstrak
Sorotan masyarakat terhadap kinerja semakin besar, terutama mengenai kurang optimal dan masih minimnya standar kinerja aparatur. Oleh karena itu perhatian terhadap kinerja maupun efektivitas kerja organisasi merupakan topik sentral menjadi isu yang ramai dibicarakan. Penelitian ini mengkaji sejauhmana pengaruh kinerja Pegawai terhadap efektivitas organisasi Dinas Pendidikan Kabupaten Tanah Bumbu. Untuk menjawab permasalahan tersebut dikaji tentang dimensi perilaku aparatur meliputi Kemampuan, keterampilan, pengetahuan,sikap dan motivasi sedangkan dimensi efektivitas organisasi tentang produktivitas kerja,efesiensi dan kepuasan kerja.Hasil penelitian ini menunjukkan di Kabupaten Tanah Bumbu perlu mengupayakan peningkatan kinerja yang menitik beratkan kepada Kemampuan, keterampilan, pengetahuan,sikap dan motivasi sebagai aset organisasi, sehingga kualitas sumber daya manusia organisasi yang bersangkutan dapat dihandalkan dalam melaksanakan pekerjaan serta kesiapan untuk menghadapi perubahan dan tantangan dimasa yang akan datang.
\end{abstract}

Kata Kunci : Perilaku pegawai, efektivitas kerja, kinerja, penilaian kinerja, kualitas SDM 


\section{PENDAHULUAN}

Dalam kehidupan modern, hampir dapat dipastikan bahwa setiap kehidupan bersama tidak akan lepas dari kehadiran Birokrasi. Demikian pula dengan negara Republik Indonesia tidak dapat melepaskan diri dari keperluan untuk menghadirikan Birokrasi di dalam pengelolaan organisasi pemerintahan. Pergantian orde pemerintahan dan reformasi di Indonesia, membawa dampak perubahan pada pembangunan yang telah dilaksanakan sehingga banyak terjadi perubahan dalam berbagai aspek. Keberhasilan Pembangunan Nasional antara lain tergantung dari pada keberhasilan peningkatan kinerja pegawai negeri sipil sebagai aparat negara. Oleh karena itu perhatiaan terhadap upaya peningkatan kinerja dilingkungan birokrasi, dewasa ini merupakan kebutuhan yang mendesak diperlukan adanya aparat negara yang berkualitas agar produktivitas kerja meningkat.

Produktivitas kerja aparat administrasi negara sampai sekarang tetap dianggap sebagai isu penting yang sering dibicarakan, baik oleh kalangan akademisi maupun para praktisi. Hal ini berkaitan dengan pembangunan nasional yang sedang dilaksanakan dan menekankan pentingnya kinerja di segala bidang, tidak terkecuali produktivitas kerja aparat administrasi negara.

Dilihat dari peningkatan kualitas sumberdaya manusia merupakan suatu keharusan dalam rangka meningkatkan kualitas akitvitas yang tidak hanya dilakukan secara parsial, tetapi peningkatan kualitas harus dilakukan secara total. Perubahan-perubahan yang sangat cepat mengakibatkan ketidakpastian (uncertainty) terutama aspek kehidupan masyarakat. Perubahan yang ditimbulkan oleh pembangunan dapat berakibat semakin meningkatnya tuntutan kebutuhan baik kualitas maupun kuntitas yang harus dipenuhi dan ditanggapi secara serius oleh pemerintah (Birokrasi). dalam teknologi, informasi yang sangat berpengaruh terhadap sumberdaya manusia. Adanya perubahanperubahan berbagai hal tersebut menuntut setiap organisasi untuk mampu beradaptasi, sebab organisasi yang mampu beradaptasi tetap akan bertahan dalam persaingan informasi yang sangat berpengaruh terhadap sumberdaya manusia. Dalam melakukan kegiatan operasional sehari-hari terutama pada tahun 2004 didapati beberapa kendala berkaitan dengan kinerja karyawan antara lain, banyak pekerjaan yang penyelesaiannya sering tertunda dan karyawan kurang bersemangat dalam melakukan pekerjaan

Menurut Cumming dan Scwhab (2000:73). Banyak faktor yang memberikan pengaruh terhadap suatu kinerja, namun secara garis besar terdapat dua faktor dominan yang berpengaruh terhadap suatu kinerja yaitu Faktor lingkungan (environment ) dan faktor individu. Jadi dalam upaya meningkatkan kinerja di Dinas Pendidikan kabupaten Tanah Bumbu, kedua hal tersebut menjadi perhatian utama dalam pengembangan sumber daya manusia.

Instansi pemerintahan merupakan suatu organisasi (wadah), maka pegawai pemerintah atau pegawai negeri adalah alat yang menggerakan dan menggiatkan agar segala kegiatan organisasi tersebut dapat berjalan menuju pada tujuan. Adapun yang dimaksud dengan Pegawai Negeri menurut Undang-Undang tentang Pokok-Pokok Kepegawaian No. 43/ 1999: 3 adalah setiap warga negara Republik Indonesia yang telah memenuhi syarat yang ditentukan, diangkat oleh pejabat yang berwenang dan diserahi tugas dalam suatu jabatan negeri, atau diserahi tugas negara lainnya, dan digaji 
berdasarkan peraturan perundang-undangan yang berlaku.

The Liang Gie dalam Musanef (1991:5) mengatakan bahwa Administrasi Kepegawaian adalah segenap aktivitas yang bersangkut paut dengan masalah penggunaan tenaga kerja untuk mencapai tujuan tertentu. Masalah pokoknya terutama berkisar pada penerimaan, pengembangan, pemberian balas jasa, dan pemberhentian.

Berdasarkan definisi tersebut maka yang dimaksud dengan administrasi kepegawaian adalah merupakan seni memilih pegawai baru, memberdayakan dan mempekerjakan pegawai lama sedemikian rupa, sehingga tercapai hasil yang memuaskan baik ditinjau dari tercapainya tujuan organisasi maupun dari para pegawai yang bersangkutan (Bulkia, 2018).

Pada dasarnya untuk melihat sampai sejauhmana peranan sumberdaya manusia suatu instansi, maka dapat dilihat dari hasil produktivitas kerja seorang pegawai yang ada dalam organisasi tersebut. Untuk dapat melahirkan sumber daya manusia (SDM) yang berkualitas tidak diperlukan bibit SDM yang handal, melainkan juga perlu suatu proses yang mendukung terwujudnya SDM yang produktif sesuai dengan yang diharapkan, banyak faktor yang mendorong peningkatan produktivitas kerja pegawai antara lain besar kecilnya jumlah gaji, pendidikan dan latihan, disiplin, motivasi, lingkungan dan iklim kerja, teknologi, manajemen, kesempatan berprestasi. Dalam hal ini termasuk di dalamnya kepemimpinan yang dilakukan oleh atasan kepada bawahannya.

Kabupaten Tanah Bumbu pada tahun 2003 adalah awal dibentuknya dari beberapa Dinas. Di anatarnya adalah Dinas Pendidikan yang menjadi pilar-pilar dilingkungan Kabupaten Tanah Bumbu. Sebelumnya bernama Dinas Pendidikan Kebudayaan dan Parawisata dengan ruang lingkup menangani bidang budaya. Setelah pada bulan Maret 2005 menjadi Dinas Pendidikan juga ditambah beberapa perubahan dalam strukturnya sehingga ruang lingkup lebih terfokus pada sektor pendidikan saja..

Dari sisi kepemimpinan merupakan faktor yang memiliki peranan yang cukup dominan di antara sekian banyak faktor yang mempengaruhi terhadap peningkatan kinerja pegawai. Di lingkungan kerja, apabila dipimpin oleh orang yang pantas untuk menduduki jabatan dan terdapat pegawai yang profesional maka tugas-tugas dari negara untuk mencapai tujuan negara, terutama tujuan pembangunan akan berjalan lancar sesuai dengan apa yang diharapkan. Oleh karena itu, segenap pegawai pemerintah harus tetap dibina secara terarah dan terus menerus melalui pembinaan profesionalisme kerja agar produktivitas kerja meningkat.

Upaya meningkatkan kinerja pegawai pada Dinas Pendidikan Kabupaten Tanah Bumbu, diperlukan pemimpin yang tangguh dalam mengelola Dinas Pendidikan tersebut. Seorang pemimpin harus dapat menggerakan bawahannya, agar rencana kerja yang telah dibuat dan tujuan yang telah ditetapkan dapat dicapai. Hal ini sesuai dengan pendapat Newstrom and Davis (1993:222), Leadership is the process of the influencing and supporting others to work enthusiastically toward achieving objectives. Pendapat di atas menunjukkan dengan jelas, bahwa faktor kepemimpinan merupakan motor atau daya penggerak dari semua kegiatan untuk mencapai tujuan organisasi yang telah ditetapkan sebelumnya.

Sebagian bentuk tugas yang dilaksanakan oleh Dinas Pendidikan adalah menganalisis kemampuan pegawai pertahun dan pengusulan berkas kenaikan pangkat. Namun kenyataannya bentuk tugas yang 
dilaksanakan ini belum secara optimal mencapai sasaran yang diinginkan. Dalam hal ini masih banyak pelanggaranpelanggaran seperti: motivasi kerja rendah sehingga seringkali pegawai menumpuk pekerjaannya, adanya pegawai yang mengerjakan tugas yang bukan pekerjaannya, kurangnya rasa tanggungjawab pegawai pada pekerjaan disebabkan belum tumbuh rasa memiliki di antara para pegawai bahkan masih saling tergantung kepada yang lainnya, sehingga pekerjaan tidak dapat ditangani, dan hasilnya tidak memenuhi harapan, misalnya banyak berkas yang hilang dikarenakan tidak adanya kepastian tentang pegawai pelaksananya. Apabila pelanggaran ini terus terjadi akan mengakibatkan turunnya kredibilitas pegawai dan kantor Dinas pendidikan tempat mereka bekerja.

Dengan adanya fenomena di atas, sering terjadi keluhan masyarakat terhadap perilaku pegawai dan berbagai pandangan di atas sering menyudutkan pegawai juga mempersulit perananya untuk mampu bekerja lebih efektif, jika keadaan ini terus berkembang, maka efektivitas kerja tidak akan dapat tercapai secara maksimal, dan akan berakibat menurunnya kualitas maupun kuantitas kerja pegawai, selain daripada itu dalam melaksanakan pekerjaan tingkat efesiensi menjadi rendah..Disamping itu menimbulkan ketidakpuasan dari para pegawai yang melaksanakan dan akan berakibat pada ketidak puasan masyarakat karena tidak dapat menerima pelayanan yang maksimal dari pegawai pada Dinas Pendidikan Kabupaten Tanah Bumbu Berdasarkan uraian tersebut di atas, penulis bermaksud untuk mengkaji mengenai Pengaruh Perilaku Pegawai Terhadap Efektivitas Kerja Pada Dinas Pendidikan Kabupaten Tanah Bumbu.

$$
\text { Berdasarkan uraian di atas dapat }
$$

dikemukakan permasalahannya adalah sebagai berikut :Seberapa besar pengaruh perilaku pegawai (kemampuan, keterampilan, pengetahuan dan sikap ) yang ditampilkan aparatur birokrasi terhadap efektivitas kerja pada Dinas Pendidikan Kabupaten Tanah Bumbu.dan seberapa besar berpengaruh motivasi yang ditampilkan pegawai terhadap efektivitas kerja pada Dinas Pendidikan Kabupaten Tanah Bumbu.

\section{Kajian Pustaka}

\section{Perilaku pegawai}

Perilaku pegawai dalam bekerja dapat dipengaruhi oleh seberapa jauh kebutuhannya dipenuhi dengan bekerja. Jika instansi/dinas di mana mereka bekerja mampu memenuhinya, maka akan menimbulkan kepuasan atas pemenuhan kebutuhannya. Dengan demikian diharapkan para pegawai akan melaksanakan pekerjaanya dengan baik. Tetapi instansi/dinas tidak akan mungkin memenuhi semua kebutuhan para pegawai yang beraneka ragam tersebut. Oleh karena itu instansi/dinas hendaknya memperhatikan kebutuhan-kebutuhan para pegawai dalam cakupan keinginan dan kebutuhan instansi yang bersangkutan. Artinya ada titik temu antara keinginan dan kebutuhan para pegawai dengan kebutuhan dan keinginan instansi/dinas.

Kemampuan adalah kualitas untuk dapat melakukan sesuatu. Ada garis tipis antara keterampilan dan kemampuan (Jaya, 2012). Kebanyakan orang akan mengatakan pembeda adalah apakah hal tersebut dipelajari atau bawaan. Saya menganggap organisasi dan prioritas sebagai kemampuan yang dapat membantu karyawan mengembangkan keterampilan desain instruksional mereka.

Keterampilan berhubungan dengan kemampuan untuk secara fisik melakukan 
suatu kegiatan atau tugas. Ini termasuk gerakan fisik, koordinasi, ketangkasan, dan penerapan pengetahuan (Fadhil, 2016). Kompetensi dan kecakapan dalam pelaksanaan keterampilan membutuhkan pelatihan dan latihan. Keterampilan diukur dalam hal kecepatan, ketepatan, dan / atau teknik melalui pengamatan atau pemantauan (Irawan, Maarif, Affandi, 2015). Keterampilan biasanya dipelajari melalui transfer pengetahuan. Biasanya, seseorang memperoleh pengetahuan tentang bagaimana melakukan suatu tugas dan kemudian mulai secara fisik melakukan tugas tersebut. Sebagai contoh, seseorang biasanya akan mempelajari bahan-bahan dan langkah-langkah yang terlibat dalam membuat kue (pengetahuan), dan kemudian secara fisik membuatnya (keterampilan).

Pengetahuan adalah kondisi sadar akan sesuatu. Ini adalah pemrosesan informasi secara kognitif. Ini mencakup penarikan kembali, pengakuan, pemahaman, penerapan, dan evaluasi fakta, pola, dan konsep. Pengetahuan dapat diukur dengan ujian tertulis atau lisan di mana seseorang mendokumentasikan atau menjelaskan apa yang mereka ketahui (Fadhil, 2016). Pengetahuan tentang fakta dan konsep membentuk dasar bagi kemampuan untuk menerapkan keterampilan untuk melakukan tugas atau untuk mengubah suatu sikap. Seseorang perlu memiliki pengetahuan dasar tentang subjek sebelum mengembangkan keterampilan atau sikap. Sebagai contoh, seseorang perlu mempelajari bahan-bahan dan langkahlangkah yang terlibat dalam membuat kue (pengetahuan) sebelum mereka benar-benar melakukan tugas membuatnya (keterampilan).

Sikap adalah cara berpikir atau perasaan tentang seseorang atau sesuatu. Ini mencakup cara seseorang menangani hal-hal secara emosional, dan itu sering tercermin dalam perilaku seseorang (Murti \& Srimulyani, 2013). Sikap seseorang dapat secara signifikan memengaruhi perasaan, nilai, penghargaan, dan motivasi terhadap sesuatu. Pengembangan atau penyesuaian sikap seseorang mungkin membutuhkan banyak waktu dan upaya. Seringkali tidak mudah untuk mengubah sikap seseorang setelah sikap itu dibentuk dalam waktu yang lama. Selain itu, sulit untuk mengukur perasaan dan persepsi seseorang tentang sesuatu. Bahkan lebih sulit untuk mengukur seberapa banyak perubahan terjadi dalam sikap seseorang sebagai hasil dari pelatihan atau kegiatan pendidikan.

\section{Efektifitas Kerja}

Efektivitas berarti 'melakukan hal-hal yang benar atau menyibukkan diri dengan hal-hal yang benar. Konsep 'efektivitas' dikaitkan dengan asumsi bahwa organisasi berorientasi pada tujuan (Fauziah \& Hidayat, 2016). Fokusnya adalah pada pencapaian aktual dari tujuan organisasi dan bukan pada cara yang diperlukan untuk mencapai mereka atau kecepatan di mana mereka tercapai. Karena alasan ini, tidak semua yang efektif harus efisien; tetapi segala sesuatu yang efisien harus efektif.

Efektivitas sangat penting untuk meningkatkan hasil; dan agar dapat bekerja secara efektif, kejelasan diperlukan. Jika karyawan tidak tahu hasil apa yang diharapkan dari mereka, ada risiko bahwa mereka akan bekerja tetapi tidak akan melakukan (Machmud, 2013). Mereka tidak melakukan hal-hal yang benar dan oleh karena itu berkontribusi tidak cukup bagi keberhasilan organisasi.

Bekerja secara efektif dan efisien adalah tanda-tanda yang jelas dari kinerja yang baik, meskipun variabel saling tergantung. Tetapi tidak hanya variabel saling mempengaruhi, mereka juga mempengaruhi dan dipengaruhi oleh faktor lain. Kejelasan peran, misalnya, 
adalah kunci bagi karyawan untuk dapat bekerja secara efektif dan efisien. Kejelasan peran penting untuk menciptakan suasana kerja yang baik dan produktif. Selama karyawan tahu apa tugas mereka, cara terbaik adalah melakukan tugas mereka, dan apa prioritas untuk setiap tugas, mereka akan merasa lebih sedikit tekanan saat bekerja dan akan lebih produktif. Memiliki gambaran yang jelas tentang peran mereka membuka jalan bagi kerja yang efektif dan efisien. Selain itu, ini akan merangsang karyawan untuk menemukan cara yang bahkan lebih efektif dan efisien untuk mencapai tujuan mereka, dan organisasi. Ini memiliki pengaruh langsung terhadap kinerja (Kultsum, 2017).

Kepemimpinan juga memainkan peran besar dalam kejelasan peran dan produktivitas. Seorang penyelia atau manajer yang menggambarkan kepemimpinan yang hebat akan memotivasi karyawan dan memberikan kejelasan dan umpan balik jika perlu; dengan demikian memungkinkan karyawannya bekerja lebih keras, untuk bekerja lebih efektif dan efisien dan menghasilkan lebih banyak dengan sedikit usaha (Darmawan, 2019).

\section{METODE}

Penelitian ini metode yang dipakai adalah kuantitatif dengan mempergunakan desain explanatory survey melalui path analysis. Hubungan kausalitas dengan melihat besarnya pengaruh dari suatu variabel penyebab ke variabel terikat. Dalam penelitian ini perilaku pegawai ditentukan sebagai variabel independent variable dan efektivitas kerja ditentukan sebagai variabel dependent variable. (Kerlinger ,1990)

\section{SAMPEL}

Mengingat perilaku pegawai yang terjadi dalam satu kantor dinas, maka memperhitungkan sampel menggunakan rumus sampling. Artinya sebuah sampel yang diambil sedemikian rupa sehingga setiap unit penelitian atau setiap elemen dari populasi tiap Sub Dinas.

\section{SAMPEL DAN RESPONDEN}

Rumus yang digunakan untuk menentukan ukuran sampel sebagai berikut :

$$
\begin{aligned}
& n=\frac{(Z \alpha+Z \beta)^{2}}{U^{2}}+3 \\
& U p=1 / 2 \operatorname{Ln}\left\{\frac{1+\rho}{1-\rho}\right\}
\end{aligned}
$$

Keterangan :

$\mathrm{N}=$ Ukuran sampel

$\mathrm{Z} \alpha$ =Harga yang diperoleh dari tabel distribusi normal baku dengan alpha yang ditemukan.

$Z \beta=$ Harga yang diperoleh dari tabel distribusi normal baku dengan betha yang ditentukan.

$\alpha=$ Kekeliruan tipe $1 ; \beta=$ kekeliruan tipe 2

(Machin \& Campbell, 1989 : 89 - 93)

Jika $\alpha=0.05 ; \beta=0.05$ dan $\rho=0.30$, maka akan diperoleh sampel tertentu, yang kemudian dialokasikan secara proporsional kepada Satuan Sampling Primer (SSP) dan selanjutnya ditentukan Satuan Sampling Sekuder (SSS), proses pengolahan dengan program SPSS versi 14.0

Iterasi pertama :

$\mathrm{Up}=1 / 2 \operatorname{Ln}\left\{\frac{1+\rho}{1-\rho}\right\}+\frac{\rho}{2(\mathrm{n}-1)}$

Jika nilai :

$$
\begin{array}{ll}
\rho & =0.30 \\
\frac{\alpha}{2} & =0,025 \cdot Z_{1}-\frac{\rho}{2}=1,96 \\
\frac{\beta}{2} & =0,025 \cdot Z_{1}-\frac{\beta}{2}=1,96
\end{array}
$$

Ukuran sampel adalah : 


$$
\begin{array}{ll}
\mathrm{Up} & =1 / 2 \operatorname{Ln}\left\{\frac{1+0,3}{1-0,3}\right\} \\
& =0.309519 \\
& =\frac{(1,96+1,96)}{0,309519}+3 \\
\mathrm{n} & =52.6460=53 \\
\mathrm{n}(\text { pembulatan) } &
\end{array}
$$

Ukuran sampel minimum sebesar 53, tetapi dalam pengambilan sample dengan menggunakan teknik Stratified Two Stages Cluster Sampling, $\mathrm{n}$ harus dikalikan dengan deff ( desaign effect), yang besarnya 2, artinya $\mathrm{n} \times$ deff $=106$.orang. selanjutnya jumlah sampel tersebut ditentukan secara proporsional berdasarkan klasifikasi untuk dijadikan sebagai responden penelitian. Adapun banyaknya responden terpilih dalam setiap strata golongan yang ada di Dinas Pendidikan Kabupaten Tanah Bumbu sebesar 106 responden.

\section{HASIL DAN PEMBAHASAN \\ Hasil}

Dari data terlihat apakah ada hubungan antar variable bebas (perilaku pegawai) dengan variable terikat (efektivitas kerja), dilakukan hitungan koefesien sederhana dengan bentuan program Statistik dalam matriks dengan hasil pada table 1. Setelah matriks korelasi di atas, proses selanjutnya adalah memisahkan variabel independennya ke dalam sebuah matriks tersendiri sebagaimana terlihat pada Tabel 2. Selanjutnya dilakukan perhitungan matriks invers korelasi dan diperoleh hasil pada tabel 3

Tabel 1. Matrik Korelasi antar Variabel

\begin{tabular}{|l|l|l|l|l|l|}
\hline 1.00000 & 0.76520 & 0.78166 & 0.71629 & 0.75388 & 0.784200 \\
\hline 0.76520 & 1.00000 & 0.69331 & 0.56199 & 0.66069 & 0.600190 \\
\hline 0.78166 & 0.69331 & 1.00000 & 0.67910 & 0.61042 & 0.691250 \\
\hline 0.71629 & 0.56199 & 0.67910 & 1.00000 & 0.59446 & 0.630000 \\
\hline 0.75388 & 0.66069 & 0.61042 & 0.59446 & 1.00000 & 0.565750 \\
\hline 0.78420 & 0.60019 & 0.69125 & 0.63000 & 0.56575 & 1.000000 \\
\hline
\end{tabular}

\section{Sumber: Data diolah, 2019}

Tabel 2. Matrik Korelasi antar Variabel

\begin{tabular}{|l|l|l|l|l|l|}
\hline 1.00000 & 0.76520 & 0.78166 & 0.71629 & 0.75388 & 0.784200 \\
\hline 0.76520 & 1.00000 & 0.69331 & 0.56199 & 0.66069 & 0.600190 \\
\hline 0.78166 & 0.69331 & 1.00000 & 0.67910 & 0.61042 & 0.691250 \\
\hline 0.71629 & 0.56199 & 0.67910 & 1.00000 & 0.59446 & 0.630000 \\
\hline 0.75388 & 0.66069 & 0.61042 & 0.59446 & 1.00000 & 0.565750 \\
\hline 0.78420 & 0.60019 & 0.69125 & 0.63000 & 0.56575 & 1.000000 \\
\hline
\end{tabular}

Sumber: Data diolah, 2019 
Tabel 3. Matriks Invers

\begin{tabular}{|l|l|l|l|l|}
\hline 2.37932 & -0.90835 & -0.03552 & -0.81827 & -0.31484 \\
\hline-0.90835 & 2.86018 & -0.79310 & -0.21604 & -0.81004 \\
\hline-0.03552 & -0.79310 & 2.18337 & -0.49176 & -0.52776 \\
\hline-0.81827 & -0.21604 & -0.49176 & 2.09906 & -0.23727 \\
\hline-0.31484 & -0.81004 & -0.52776 & -0.23727 & 2.21563 \\
\hline
\end{tabular}

\section{Sumber: Data diolah, 2019}

Selanjutnya dari hasil korelasi matriks invers, dilakukan hitungan koefisien jalur dari masing-masing sub variabel bebas (Xi) terhadap variabel terikat (Y) dan diperoleh besarnya koefisien jalur untuk masingmasing sub variabel sebagai berikut :

$\mathrm{PYX} 1=0.221$

$\mathrm{PYX} 2=0.174$

PYX3 $=0.132$

PYX4 $=0.249$

PYX5 $=0.307$

Untuk mengetahui seberapa besar pengaruh bersama variabel bebas (perilaku aparatur birokrasi) terhadap varibel terikat (efektivitas kerja organisasi) maka dilakukan perhitungan koefisien determinasi yang merupakan koefisien yang menyatakan determinasi total dari semua variabel penyebab terhadap variabel akibat. Setelah dilakukan perhitungan maka besar koefisien determinasi :

$\mathrm{R} 2 \mathrm{YX} 1 \ldots . \mathrm{Xk}=0.829$

Langkah selanjutnya melakukan hitungan pengaruh variabel lain yang tidak dimasukan ke dalam model dan besar pengaruh variabel lain tersebut adalah $\square 2=0.171$

Selanjutnya untuk mengetahui apakah koefisien jalur tersebut bermakna atau tidak terhadap hipotesis :

$\mathrm{H} 0$ : $\mathrm{PYX} 1=\mathrm{PYX} 2=\mathrm{PYX} 3=\mathrm{P} \neg \mathrm{YX} 4=$ $\mathrm{PYX} 5=0$

$\mathrm{H} 1: \mathrm{PYXi} \neq 0$

Adapun kriteria uji adalah :
Tolak H0 jika nilai F>F $\square ; k ;(n-k-1)$

$\mathrm{F}$ hitung $=106.385$

$\mathrm{F}$ tabel $=2.30$

Maka :

$\mathrm{F}$ hitung $>\mathrm{F}$ tabel maka $\mathrm{H0}$ ditolak artinya H1 diterima (sekurang-kurangnya ada satu koefisien jalur, PYXi $\neq 0$ )

Artinya :

Apabila setiap sub variabel pada variabel bebas (X) digabungkan secara bersama-sama akan mempengaruhi variabel $\mathrm{Y}$ sebesar $82,9 \%$ sedangkan $17,1 \%$ perubahanperubahan yang terjadi pada variabel $Y$ yang dipengaruhi oleh variabel lain selain oleh sub variabel - sub variabel pada variabel bebas (X).

Selanjutnya untuk mengetahui koefesien jalur (PYXi) mana yang tidak sama dengan nol, maka langkah selanjutnya adalah dengan melakukan pengujian koefisien jalur secara individual dengan menentukan hipotesis statistik yang akan diuji yaitu :

$\mathrm{H} 0: \mathrm{PYXi}=0$

$\mathrm{H} 1: \mathrm{PYXi}>0$

dan kriteria pengujian, tolak $\mathrm{H} \neg 0$ jika nilai $\mathrm{t}$ $>\mathrm{t}$ (1- $\square)$;(n-k-1), berdasarkan hasil program MINITAB diperoleh nilai untuk setiap $t$ sebagai berikut :

$\mathrm{t} 1=3.637$

$\mathrm{t} 2=2.613$

$\mathrm{t} 3=2.267$

$\mathrm{t} 4=4.356$

$\mathrm{t} 5=5.217$

dengan nilai $\mathrm{t}$ tabel $=1.66$ 
setelah membandingkan nilai-nilai t1 terhadap ttabel maka terlihat bahwa nilai $\mathrm{t} \neg 1$, sampai t5 lebih besar dari nilai t tabel, maka pengaruh dari masing-masing individu adalah signifikan dan $\mathrm{H} 0: \mathrm{PYXi}=0$ ditolak.

Dari hasil tersebut dapat diartikan bahwa Variabel Efektivitas Kerja (Y) dipengaruhi secara langsung oleh sub variabel kemampuan (X1) sebesar (0.221)2 atau sebesar $0.04884 \quad$ (4.90\%). Variabel Efektivitas Kerja (Y) dipengaruhi secara langsung oleh sub variabel keterampilan (X2) sebesar (0.174)2 atau sebesar 0.0303 (3.03\%). Variabel Efektivitas Kerja (Y) dipengaruhi secara langsung oleh sub variabel pengetahuan (X3) sebesar (0.132)2 atau sebesar 0.0174 (1.74\%). Variabel Efektivitas Kerja (Y) dipengaruhi secara langsung oleh sub variabel sikap (X4) sebesar (0.249)2 atau sebesar 0.062 (6.2\%).

Variabel Efektivitas Kerja (Y) dipengaruhi secara langsung oleh sub variabel motivasi (X5) sebesar (0.307)2 atau sebesar 0.0942 $(9.42 \%)$.

\section{Pembahasan}

Hasil penelitian menunjukkan bahwa Variabel bebas (X) atau Perilaku Aparatur Birokrasi dalam penelitian ini terdiri dari 5 (lima) sub variabel, yaitu kemampuan (X) untuk memberikan interpretasi koefesien korelasi sebesar 3,426, responden temuan data yang dideskrisikan dari pernyataan tentang mempunyai kemampuan yang kecil menuju sedang, terdapat 58,62 \% yang menyatakan kecil dan sedang terdapat, 29,32 $\%$ netral dan $6,03 \%$ sangat besar. Artinya aparatur birokrasi pada umumnya cukup mempunyai kemampuan, namun dalam hal melakukan fungsi-fungsi manajemen terutama dalam mempengaruhi pegawai agar lebih giat bekerja dan menggerakan pegawai supaya lebih efektif bekerja serta dalam melakukan komunikasi dengan pegawai di bawahan terutama menyangkut job description masih kurang.. juga dengan pernyataan tentang keterampilan pegawai sebanyak 37,93 \% menyatakan kecil dan $56,04 \%$ sangat kecil hanya sebanyak 6,03\% yang sedang. Berarti walaupun tingkat pendidikan yang dimiliki aparatur birikrasi cukup tinggi namun pada umumnya mereka berlatar belakang Sarjana Pendidikan dan hanya sebagian kecil yang berlatar belakang Sarjana Administrasi atau manajemen sehingga dalam pengelolaan pekerjaan terutama dalam mengatur pekerjaan pegawai di bawahnya mengalami banyak kesulitan. Hal tersebut terlihat dari komposisi yang menyatakan bahwa aparatur birokrasi di Dinas Pendidikan kurang terampil dalam mengatur pekerjaan pegawai.

Pernyataan tentang sikap, terdapat 54,32 $\%$ kecil, 27,58 \% sangat kecil dan sebanyak $12,07 \%$ sedang dan sebanyak $6,03 \%$ besar. Artinya aparatur birokrasi di Dinas Pendidikan menyatakan bahwa sikap yang ditampilkan oleh birokrat banyak mempengaruhi efektivitas kerja.

Pernyataan tingkat hubungan motivasi sebesar 62,93 \% menyatakan kecil sedangkan $28 \%$ sangat kecil dan sebanyak $12,93 \%$ berpengaruh sedang pada organisasi, artinya menunjukan adanya suatu ketidak puasan bawahan terhadap motivasi yang diberikan aparatur birokrasi terutama pemberiam imbalan yang kurang layak dari hasil kerja dan tidak ditetapkannya hukum atau sanksi terhadap pegawai yang melanggar peraturan sangat berpengaruh dalam membentuk karakter positif maupun negatif pegawai.

Pernyataan tentang hubungan tingkat produktivitas kerja nya kecil bahkan mengarah pada katagori sangat kecil. terdapat $38,80 \%$ tingkat hubungan kecil dan sangat kecil 55,17 \% sedangkan sebanyak 6,03\% besar dan sangat besar. Artinya Hal tersebut dapat terlihat dari banyaknya pegawai yang 
membaca koran dan ngobrol pada jam kerja dan datang terlambat kemudian pulang lebih awal.

Pernyataan tentang masalah efiseinsi kerja terdapat tingkat hubungan yang menyatakan kecil sebanyak 44,86\%, sedang sebanyak 43,19\% dan besar dan sangat besar sebanyak $7,74 \%$ sedangkan sangat kecil sebesar11,21\%. Artinya hal ini menunjukan bahwa masih sering pegawai menunda pekerjaan sehingga masyarakat yang membutuhkan pelayanan informasi yang dilakukan birokrat yang menyangkut pekerjaan pegawai sering melakukan pemborosan bahan,waktu juga biaya.

Pernyataan efektivitas kerja dalam kepuasan kerja sebanyak $62,93 \%$ kecil tingkat hubungan,13,80\% sedang, 11,21\% sangat kecil dan sebanyak 12,06\% menyatakan besar dan sangat besar. Artinya menunjukan bahwa kurangnya penghargaan dari birokrat terhadap hasil pekerjaan,dan yang cukup menarik dari kepuasan kerja adalah pegawai merasa tidak terjamin dalam mengembangkan kariernya. Hal tersebut menciptakan kondisi kerja yang kurang baik dan kurang dihargai pada diri pegawai.

Peneliti mencoba mengungkapkan secara statistik bagaimana pengaruh antara variabel bebas yaitu perilaku aparatur birokrasi dengan variabel terikat efektivitas kerja organisasi di Dinas Pendidikan Kabupaten Tanah Bumbu. Untuk mengukur seberapa besar tingkat pengaruh perilaku aparatur birokrasi terhadap efektivitas kerja organisasi, dipergunakan analisis jalur dengan pengaruh langsung variabel kemampuan (X!) sebesar 4,9 \%, keterampilan sebesar 3,03\%, pengetahuan sebesar $1,74 \%$ dan sikap sebesar $6,2 \%$ juga motivasi sebesar 9,42 \%. Besarnya perhitungan statistik yang telah dikemukakanpada bagian sebelumnya, diperoleh nilai koefisien determinan sebesar (R2 yx1....xk ) sebesar 82,8 \%. Nilai ini menandakan bahwa perilaku aparatur birokrasi sebagai variabel bebas mempunyai pengaruh yang cukup besar terhadap efektivitas kerja organisasi sebagai variabel terikat, secara statistik nilai koefisien determinasi yang dihasilkan dari pengolahan path analisis tidak dapat secara langsung digunakan untuk numerik. Kesimpulan guna menerima atau menolak hipotesis yang diajukan, karena untuk numerik suatu kesimpulan nilai koefesien determinasi tersebut harus dilakukan pengujian keberartian dengan menggunakan statistik uji F diperoleh nilai Fhitung sebesar 106,385, karena $\mathrm{F}$ hitung tabel (2.3), maka hasil ini menegaskan bahwa hipotesis yang diajukan dalam penelitian ini yaitu semakin besar pengaruh perilaku yang ditampilkan aparatur birokrasi maka akan ditampilkan efektivitas kerja organisasi di Dinas Pendidikan Kabupaten Tanah Bumbu dapat diterima dan diperoleh pembuktian secara empirik. Adapun besar variabel lain yang mempengaruhi efektivitas kerja organisasi dari hasil perhitungan analisis jalur diperoleh nilai epsilon (pye) sebesar $17,1 \%$, variabel lain tersebut terdiri dari berbagai unsur, seperti struktur organisasi, desain pekerjaan, proses dari pekerjaan lain. Dari jawaban perilaku aparatur birokrasi termasuk katagori sedang sebesar $51,9 \%$ selanjutnya $23,1 \%$ katagori sangat kecil dan responden yang menyatakan efektivitas kerja pada katagori kecil rata-rata sebesar $49,14 \%$ selanjutnya mengarah sangat kecil sebesar 23,27\%. Apabila dibandingkan koefesien determinasi dengan hasil jawaban responden pada variabel bebas $(\mathrm{X})$ dan variabel terikat $(\mathrm{Y})$, menunjukkan adanya suatu kesamaan.

Dari hasil tersebut menunjukkan bahwa efektivitas kerja organisasi di Dinas Pendidikan Kabupaten Tanah Bumbu belum terlaksana secara optimal, hal ini tercermin dari aktivitas aparatur birokrasi yang kurang memahami mekanisme kerja serta aparatur 
birakrasi yang diharapkan sebagai motor penggerak dalam menjalankan roda organisasi dan bertanggung jawab atas pelaksanaan pekerjaan sehingga tercapai tujuan yang diinginkan. Pada kenyataannya kurang optimal dalam menjalankan fungsinya. Persepsi masih terbatas pada pemahaman normatif sedangkan dinamika organisasi cendrung sering terabaikan pada hal merupakan aspek penting dari keseluruhan proses yaitu pengembangan sumber Daya Manusia. Dalam kaitan dengan penguasaan aparatur birokrasi terhadap berbagai keterampilan, pengetahuan, sikap dan motivasi. Secara normatif dapat dikemukakan bahwa semakin tinggi tingkat penguasaan aparatur birokrasi terhadap ke lima sub kelima berkaitan dengan tugas dan fungsinya, maka akan semakin besar kemungkinan efektivitas kerja organisasi akan tercapai secara optimal.

Seorang birokrasi sudah selayaknya memiliki kemampuan dalam mengambil suatu keputusan yang hasilnya tidak hanya sekelompok orang dapat mengambil manfaat dari kebijakan tersebut tetapi harus dapat dirasakan oleh setiap orang yang berada dibawah kepemimpinannya. Agar dapat menciptakan efektivitas kerja yang besar, aparatur organisasi hendaknya mempunyai kemampuan untuk belajar dari kesalahan yang pernah diperbuatnya atau kesalahan yang diperbuat orang lain dan mampu melihat dan memecahkan permasalahan dengan penuh tanggung jawab.

Secara umum uraian variabel perilaku yang ditampilkan pegawai mempunyai pengaruh yang besar terhadap efektivitas kerja. Pengaruh dari masing-masing sub variabel perilaku pegawai. Walaupun secara individual mempunyai nilai yang relatif kecil namun berada pada kategori signifikan dan apabila masing-masing sub variabel digabung secara bersama-sama dalam mempengaruhi efektivitas kerja akan mempunyai nilai pengaruh yang besar. Keadaan ini menunjukan sudah selayaknya apabila pegawai berusaha untuk meningkatkan dan memperbaiki hal-hal yang mempengaruhi perilakunya. Sebab dengan perilaku pegawai yang baik diharapkan efektivitas akan meningkat. Perilaku birokrat yang kurang baik di dalam suatu organisasi akan menyebabkan akan tidak puasnya pegawai, ketidakpuasan yang dirasakan akan menimbulkan kekurang senangan bagi pegawai sehingga mengakibatkan produktivitas dan efesiensi kerja menurun.

Ketidak puasan timbul karena kurang terpuaskannya kebutuhan baik yang bersifat material maupun non material. Ketidakpuasan tersebut dapat terjadi karena kurang terpenuhinya kebutuhan-kebutuhan seperti gaji yang layak, rasa aman, kesempatan promosi, hubungan yang harmonis dan sebagainya.

Setiap organisasi akan selalu berusaha agar efektivitas kerja dari pegawai dapat ditingkatkan, untuk itu organisasi perlu memperbaiki perilaku dari pegawai dengan meningkatkan pemberian motivasi kepada para pegawai.

\section{KESIMPULAN DAN SARAN}

\section{Kesimpulan}

Hasil perhitungan skor diperoleh kenyataan bahwa tingkat perilaku pegawai masih belum optimal, kenyataannya dari ability, skill , knowledge, attitude dan motivation. Sekalipun secara umum semua sub variabel belum optimal namun dari skor jawaban responden dapat disimpulkan bahwa knowledge dipersepsikan paling kurang oleh responden.

Hasil analisis dam perhitungan terhadap variabel terikat, diperoleh kenyataan bahwa efektivitas kerja di Dinas pendidikan Kabupaten Tanah Bumbu masih belum optimal. Hal tersebut dapat dilihat dari masih 
rendahnya produktivitas kerja yaitu efesiensi kerja dan kepuasan kerja.

Selain itu dari hasil path analisis dan hasil uji - $\mathrm{t}$ ternyata Ho diterima sehingga dapat dinyatakan bahwa masing-masing sub variabel perilaku pegawai berpengaruh secara signifikan terhadap efektifitas kerja di Dinas Pendidikan Kabupaten Tanah Bumbu.

\section{Saran}

Hasil dari penelitian ini diharapkan mampu memberikan kontribusi kepada para pengampu kebijakan terkait pengelolaan tenaga kependidikan di Kabupaten Tanah Bumbu. Dinas Pendidikan Kab. Tanah Bumbu perlu melakukan pembinanaan dalam rangka meningkatkan kemampuan para tenaga pendidik baik kemampuan mengajar maupun kemampuan adminstratif pendukung kegiatan belajar dan mengajar. Penelitian ini juga memiliki beberapa keterbatasan seperti jumlah sampel yang terbatas dan masih terdapat instrument yang mungkin memiliki tingkat yang lebih baik dalam mengukur efektifitas kerja para pendidik, terutama di Kab. Tanah Bumbu

\section{DAFTAR PUSTAKA}

Bass, B.M. 1990. Stogdil's Handbook of Leadership, A Survey of Theory and Research. Revised and Expanded Edition. New York : Free Press.

Bulkia, S., \& Herawati, A. S. (2018). Pengaruh Pelatihan dan Motivasi Terhadap Kinerja Karyawan PT. Sumber Berlian Motors KM. 5 Banjarmasin. AtTadbir: jurnal ilmiah manajemen, 2(2).

Cuming L.L \& Donal.P. Schwab, 2000. Performance In Organizational, Glenview, Illinois : Scatt, Foresman And Company.

Darmawan, D. (2019). PERANAN MOTIVASI DAN KOMPETENSI: ANALISIS KINERJA PEGAWAI PEMERINTAHAN DAERAH KABUPATEN PASER. At-Tadbir: jurnal ilmiah manajemen, 3(2).
Fadhil, M. (2016). Pengaruh Kompetensi Sumber Daya Manusia Terhadap Kinerja Pegawai Pada Balai Latihan Kerja Industri Makassar. PERSPEKTIF: JURNAL PENGEMBANGAN SUMBER DAYA INSANI, 1(1), 70-81.

Fauziah, M. I., \& Hidayat, R. (2016). PENGARUH PEMBERIAN TUNJANGAN TERHADAP EFEKTIVITAS KERJA PEGAWAI PADA BADAN PEMBERDAYAAN MASYARAKAT. Jurnal Ilmiah Publika, 4(2).

Futwengler, Dale,2002. Penuntun Sepuluh Menit Penilaian Kinerja, Terjemahan

Fandy Tjiptono. Yagjakarta

Gibson, James L: Ivancevich, John M.

Donnelly, James H JR. 1997.

Organization Behavior, Structure, Process, (Fifth Edition). Plano, Texas : Business Publications, Inc.

Hersey, Paul, Kennet H. Blanchard and Dewey F. Johnson. 1996. Management of Organizational Behavior. New Jersey : Prentice Hall International.

Instruksi Presiden Republik Indonesia Nomor 7 Tahun 1999, tentang Akuntabilitas Kinerja Instansi Pemerintah. Lembaga Administrasi Negara : Badan Pengawasan Keuangan dan Pembangunan Jakarta.

Irawan, A., Maarif, M. S., \& Affandi, M. J. (2015). Faktor-faktor yang memengaruhi kinerja pegawai negeri sipil di Direktorat Jenderal Pendidikan Tinggi. Jurnal Aplikasi Bisnis dan Manajemen (JABM), 1(1), 56.

Jaya, I. (2012). Pengaruh Kemampuan dan Motivasi Kerja terhadap Kinerja Pegawai Dinas Pendidikan Kabupaten Tanjung Jabung Barat. Jurnal Penelitian Universitas Jambi: Seri Humaniora, 14(1).

Karlinger, Fred N. 1990. Asas-asas Penelitian Behavior Yogyakarta Gajah Mada University, Press.

Kamus Besar Bahasa Indonesia. 1998. Departemen Pendidikan dan Kebudayaan. Balai Pustaka.

Keban, 1995.Indikator Kinerja Pemerintah Daerah Dalam Kebijakan, Universitas 
Gajah Mada. Yagjakarta.

Keputusan Gubernur Kalimanatan Selatan Nomor 39 Tahun 2001, tentang Tugas Pokok, Fungsi dan Rincian Tugas Unit. Dinas Pendidikan Kalimantan Selatan Kultsum, U. (2017). Pengaruh Lingkungan Kerja Dan Budaya Organisasi Terhadap Efektivitas Kerja Melalui Motivasi Kerja Sebagai Variabel Intervening Pada Pt. Trasti Global Konverta. Journal Of Business Studies, 2(2), 121-132.

Machmud, R. (2013). Peranan penerapan sistem informasi manajemen terhadap efektivitas kerja pagawai lembaga pemasyarakatan narkotika (lapastika) bollangi kabupaten gowa. Jurnal Capacity STIE AMKOP Makassar, 9(3), 409-421.

Murti, H., \& Srimulyani, V. A. (2013). Pengaruh Motivasi Terhadap Kinerja Pegawai Dengan Variabel Pemediasi Kepuasaan Kerja Pada PDAM Kota Madiun. JRMA| Jurnal Riset Manajemen dan Akuntansi, 1(1), 10-17.
Mussanef. 1991. Manajemen Kepegawaian di Indonesia. Jakarta : CV Haji Masagung

Nawawi, Hadari dan Martini. 1994. Ilmu Administrasi. Jakarta : Ghalia Indonesia.

Newstroom, John W. Davis Keith. 1993. Organizational Behavior Human Behavior at Work. Ninth Edition, United States of America : McGraw Hill, Inc.

Osborne, David, Giabler, Ted, 1999. Reinverting Goverment. Jakarta

Prawirosentono, 1999. Manajemen Sumber Daya Manusia Kebijakan Kinerja. Yogjakarta. BPFE

Republik Indonesia. Undang-undang Nomor 43 Tahun 1999 : Tentang Pokok-pokok Kepegawaian.

UUD 1945, GBHN (TAP MPR

NO.IV/MPR/1999-2004), TAP-TAP MPR. 2000, Amandemen Keempat, 2002, Bandung, CV Pustaka Setia.

Undang-undang Nomor 22 Tahun 1999, tentang Pemerintahan Daerah 